IZA DP No. 9045

Academic Performance and Type of Early Childhood Care

Nabanita Datta Gupta

Marianne Simonsen

May 2015 


\title{
Academic Performance and Type of Early Childhood Care
}

\author{
Nabanita Datta Gupta \\ Aarhus University and IZA \\ Marianne Simonsen \\ Aarhus University and IZA \\ Discussion Paper No. 9045 \\ May 2015 \\ IZA \\ P.O. Box 7240 \\ 53072 Bonn \\ Germany \\ Phone: +49-228-3894-0 \\ Fax: +49-228-3894-180 \\ E-mail: iza@iza.org
}

\begin{abstract}
Any opinions expressed here are those of the author(s) and not those of IZA. Research published in this series may include views on policy, but the institute itself takes no institutional policy positions. The IZA research network is committed to the IZA Guiding Principles of Research Integrity.

The Institute for the Study of Labor (IZA) in Bonn is a local and virtual international research center and a place of communication between science, politics and business. IZA is an independent nonprofit organization supported by Deutsche Post Foundation. The center is associated with the University of Bonn and offers a stimulating research environment through its international network, workshops and conferences, data service, project support, research visits and doctoral program. IZA engages in (i) original and internationally competitive research in all fields of labor economics, (ii) development of policy concepts, and (iii) dissemination of research results and concepts to the interested public.
\end{abstract}

IZA Discussion Papers often represent preliminary work and are circulated to encourage discussion. Citation of such a paper should account for its provisional character. A revised version may be available directly from the author. 
IZA Discussion Paper No. 9045

May 2015

\section{ABSTRACT}

\section{Academic Performance and Type of Early Childhood Care*}

This is one of the few studies that estimates the effects of type of childhood care on academic achievement at higher grade levels by linking day care registers and educational registers. We use entire birth cohorts of ethnic Danish children, enrolled in either center based day care or family day care at age 2. Exploiting variation across municipalities in guaranteed access to center based care as an instrument for type of care our results show that center based day care improves grades in Danish language in the final year of compulsory school with around 0.2 standard deviations.

JEL Classification: J13

Keywords: center based care, family day care

Corresponding author:

Marianne Simonsen

Department of Economics and Business

Aarhus University

Fuglesangs Allé 4,

DK-8210 Aarhus $V$

Denmark

E-mail: msimonsen@econ.au.dk

\footnotetext{
* We thank Kasper Jørgensen and Boris Georgiev for able research assistance. We appreciate valuable comments from Peter Allerup, Silke Anger, Peter Haan, Helena Skyt Nielsen, Astrid Würtz Rasmussen, C. Katharina Spiess, Tea Trillingsgaard, Katharina Wrölich, workshop participants at Aarhus University's Research Center in Early Interventions (AU RECEIV) December 2012 workshop, and seminar participants at the DIW Berlin's May 2013 seminar series and Trygfonden's Child Research seminar series. We are grateful to Bureau 2000 who provided us with access to data on day care policy variation across municipalities.
} 


\section{Introduction}

A rather large literature exists on the effects on child development of maternal employment outside the home during a child's early years (Blau \& Currie, 2006); see for example recent work by Bettinger, Hægeland and Rege (forthcoming) and Schönberg and Ludsteck (forthcoming). Whether maternal employment has negative or positive effects on child outcomes depends, of course, to a large extent on the quality of counterfactual care. A growing literature on the effects of child care has shown that high-quality programs targeted at children from lower socioeconomic strata can be highly cost-effective in the long-run (Heckman, 2008; Almond and Currie 2011). Exposing children of low-income families to a stimulating and nurturing environment from early childhood (for instance, especially the Perry Preschool program in the US) gives strong returns in the long-run (Duncan and Magnuson, 2013). Recent evidence from the Infant Health and Development Program is presented in Duncan and Sojourner (2013). The development of key skills at an early age is crucial for vulnerable children because they promote the building of later skills through both self-productivity and dynamic complementarity.

This paper is concerned with the consequences of parents' decisions about childcare, given that they have decided to place the child in out-of-home care. The paper is thus one of the few to bring evidence on the effects of different modes of childcare on child outcomes and our particular study focuses on center based day care versus family day care; see also Bernal and Keane (2011) for a study on children born to single mothers.

Our analysis uses comprehensive Danish register data to look at long-term, high-stakes outcomes i.e. the effects on children's school final year (9th grade) GPA and on the probability of enrolling 
in high school before the age of $17,{ }^{1}$ while exploiting municipal variation in access to different types of care. Why should attending formal child care at an early age be expected to impact a child's long run academic achievement? According to the early childhood education view, trained and educated child minders can give children an early start in learning important cognitive skills such as math and language at a stage when neuroplasticity of the brain is at its highest level and the development of synapses in its accelerating phase (ages 0-3) (Shonkoff and Phillips, 2000). Furthermore, being exposed from an early age to various peers fosters the development of valuable socio-emotional or non-cognitive ("soft”) skills as well. For children of low educated parents in particular, care of this type could be a way to close socioeconomic achievement gaps that begin to open up from a very early age (Heckman, 2008).

While most studies find early gains in achievement from child care or pre-kindergarten, these effects for the most part seem to fade out, as early as the end of kindergarten (Duncan and Magnuson, 2013). Yet, large positive long-run effects of exposure to child care on employment, crime and welfare have been found (Deming, 2009; Havnes and Mogstad, 2011), presenting a real puzzle in the literature as to the validity of such long-run effects. One explanation for finding a long run effect could be that the early exposure to skill formation lays the foundation for greater self-productivity at later stages, for instance when more advanced material is introduced in the curriculum. Another could arise from a dose response relationship in child care, such that high quality, full time care (such as in Scandinavia) could lead to potentially longer lasting effects (Shonkoff and Phillips, 2000).

\footnotetext{
${ }^{1}$ Completion of high school given enrolment is also an important outcome. Unfortunately, the children in our estimation sample are still too young to allow for such an analysis.
} 
The use of register data on the entire population of Danish children is expected to bring more precise and robust evidence to these questions compared to a range of previous studies. By looking over a longer-time span, from age 2 to age 16, we are able to map the longer-run consequences of early childhood care. Because we observe test scores of children at age 16, we are one of the first studies to be able to bring large-scale evidence on the question of the long-run academic fadeout of the effects of early childcare. Also, as opposed to some of the prominent previous papers (Baker et al., 2008; Havnes and Mogstad, 2011) the data permit us to identify direct treatment effects because individual level childcare enrolment is registered and can be linked to educational registers.

We find that being enrolled in center based day care at age 2 significantly increases $9^{\text {th }}$ grade overall GPA in Danish language with around 0.2 standard deviations. Effects on overall math GPA are smaller (0.1 standard deviations) and not significant in most specifications. Because most children initially enrolled in family day care eventually enrol in center based care, the appropriate interpretation of our results is as the consequence of an additional $1 \frac{1 / 2}{2}$ years of early center based care. To put the size of the estimated effects into perspective, the results on Danish language correspond to enrolling about seven extra students into a Swedish classroom for children aged 10-13 (Fredriksson, Öckert and Oosterbeek, 2013) or to about 200 additional school days (Carlsson, Dahl, Öckert and Rooth, 2013). We also find some evidence that the probability of being enrolled in high school at age 16 is increased as a consequence of center based day care. Results are robust to a range of alternative specifications, including a complementary instrumental variables strategy that exploits municipality variation in the size of the population aged 0-6. These findings give important input to the next generation of studies on the quality rather than the quantity of child care. 
The paper is structured as follows: Section II discusses related literature, Section III provides institutional details about Danish child care, and Section IV describes our data and the empirical methods employed. Section V presents results and Section VI concludes.

\section{Related literature}

Of most interest to us are studies that compare different types of non-parental care. A prominent example is Bernal and Keane (2011) who find negative effects of non-parental care on cognitive outcomes for children of single mothers but conclude that this is completely driven by non-center based care. Center based care, on the other hand, has no adverse effects. Earlier Danish studies (Datta Gupta \& Simonsen 2010, 2012) utilized variation across municipalities in the supply of family day care and pre-school slots to estimate the effects of different modes of care on child outcomes. These studies thus used an IV strategy which informed on the direct effect of a specific treatment. The child outcome was parent-reported SDQ behavioural scale ${ }^{2}$ at school starting age and at age 11, low-stakes, surveyor-administered cognitive tests and a number of self-reported non-cognitive skills. Both studies utilized a random sample of around 6,000 children from the 1995 birth cohort followed over time in a rich longitudinal survey collected by SFI-The Danish National Centre for Social Research. The results showed that there was a positive effect on child behavior at school starting age of having attended center based preschool compared to family day care at age 3 ; however, at age 11, because of smaller sample sizes due to attrition from the survey, effects were imprecisely estimated. Thus, no significant differences

\footnotetext{
${ }^{2}$ The Strength and Difficulties index, or SDQ, is a widely accepted index of behavioural problems used by child psychologists, similar to the Rotter Scale. It ranges from $0-40$ and is increasing in behavioural problems; see Goodman (1997).
} 
could be identified in either cognitive or non-cognitive skills across the two groups of children although children who had been in preschool care showed higher school likeability.

Another relevant strand of literature is concerned with the effects of universal schemes per se. Universal child care in Denmark has existed since the 1970s, and evidence from such a regime reliably represents the long-run effects of a scheme that has matured over time as opposed to a scheme in its infancy. The focus on universal care is particularly relevant because of the increased political interest in and support for such programs, not just in Scandinavia, but also in the US, as was highlighted in President Obama's 2013 State of the Union speech. Similarly, in the EU, policymakers are calling for wider provision of child care both for the purpose of substantially increasing women's attachment to the labour force by reconciling work life and family life, and as a response to declining fertility rates. Because peer effects can be quite different in universal schemes as opposed to schemes targeting mainly low SES children ${ }^{3}$, evidence from such schemes can give important input to the debate on the effect on achievement vs. equality of institutionalized child care.

Most studies that exist on the effects of child care on children in universal child care schemes exploit the introduction of such child care for identification purposes and results are mixed. This may to some extent be because the counterfactual mode of care varies across studies. Baker et al (2008) exploit the introduction of universal (\$5-a day) child care in Quebec. Using before-after, Quebec-rest of Canada differences, their results show negative effects on parental stress and

\footnotetext{
${ }^{3}$ See e.g. Herbst and Tekin (2012), on the effect of CCDF subsidies to low-skilled parents on child development, or Bernal and Keane (2011), on the effects on children's cognitive achievement of child care choices made by single mothers.
} 
relationship outcomes and on a host of child behavioural outcomes such as aggression, motor social skills and illness. They cannot rule out, however, that these negative effects reflect a shortterm adjustment to the sharp shift in the supply of child care that occurred over a very short period of time and hence not necessarily a long-term effect. Felfe, Nollenberger and RodriguezPlanas (2012) consider the introduction of universal care for 3-year-olds in Spain and find sizable improvements in children's reading and math skills at age 15, as well as in grade progression during primary and secondary school. Felfe and Lalive (2013) investigate the effects of the expansion of early (starting-age less than $21 \frac{1}{2}$ ) center based care in the Schleswig-Holstein region in Germany. They find that children gain in terms of school entry assessments. A complementary study by Dustmann, Raute and Schönberg (2013) investigate universal care for 3- to 6-year-olds in the mostly-rural Weser-Ems region in Germany while relying on staggered introduction across municipalities. Interestingly, they find gains in terms of language and motor skills measured in connection with school start for the population of immigrant children but no significant effects for native children. Cascio and Schanzenbach (2013) put together data from various sources to try to estimate the effects of the introduction of high-quality "preschool for all” programs adopted in Georgia and Oklahoma on a range of child and family outcomes. Comparing these two states to the rest of the US and also comparing families with 5 year olds to families with 4 year olds, their DD and DDD results show that following the introduction of these programs, preschool enrolment, maternal time spent on reading to the child and child test performance increases for low-income children. For high-income children, however, the programs mainly appear to shift enrolment from private to public preschool and have no discernable impact on their test scores, but do reduce child care expenditures. 
Evidence on long-term effects of universal child care is scarce. A Norwegian study by Havnes \& Mogstad (2011) exploits the expansion of universal child care in Norway in the 1970s and 1980s and provides evidence on the long-term outcomes of child cohorts exposed to the period of expansion. They find strong positive effects on higher education (high school completion and college enrolment), an equalizing effect on the earnings distribution and a lowering effect on zero earnings, welfare dependency and early family formation, in short, overwhelmingly positive and equalizing effects of day care expansion. ${ }^{4}$

To sum up, most of the earlier literature has been concerned with measuring effects on children and families of large-scale child care expansions introducing a non-home based care option for the first time. A second generation of studies is turning its attention to effects of the quality rather than quantity of child care. We are one of the few in this area to bring direct evidence originating from a mature child care regime on the long-run effects on children of different modes (quality) of child care making use of linked day care registers and educational registers.

\section{Center based day care vs. family day care}

Day care in Denmark is, on average, of relatively high quality, having one of the highest staffchild ratios in the OCED (see Datta Gupta et al. 2008). For the 0-2 age group, regulated public

\footnotetext{
${ }^{4}$ Related to this issue, Black et al. exploit a sharp discontinuity in the price of child care in Norway and find little effect on child care utilization or parental labor supply but strong effects on children’s academic performance at junior high school (Black et al., 2012). The most likely mechanism seems to be the increased disposal income to families during childhood. It is not surprising that the effect seems to fall on income rather than on child care utilization. At age 5, most children in Scandinavia would be enrolled in some form of day care already.
} 
day care is either center based or more informal, family run, i.e. taking place at the home of a carer (99\% of whom are female) who minds a group of up to 5 children of varying ages but rarely above the age of 4 . Both types of day care — center based or family_are regulated by the state regarding educational content, safety and hygiene. Core center staff must hold a pedagogical degree (15-16 years of education) while family carers are offered shorter vocational courses. In fact, Datta Gupta and Simonsen (2010) show that the vast majority of family day carers (92\%) either holds a vocational degree (54\%) or has high school or less education (38 $\%)$.

The staff-child ratio is about the same across the two types of care; centers on average employ 2 adults ( 1 teacher, 1 helper) per 7 children. The yearly expenditure per day care slot is $\$ 9,000$ for centers and about $\$ 10,000$ for family carers, however parents pay a maximum of 33\% of the costs, meaning up to $\$ 3,500$ for a family day care slot and $\$ 2,600$ for a slot in a day care center. Parents with an annual income of above $\$ 60,000$ pay the full cost whereas those with an annual income of less than $\$ 20,000$ do not pay for day care (for details of the pricing scheme, see Simonsen, 2010). Appendix A details the child care allocation mechanism.

Child development researchers claim that the optimal measure of child care quality is process quality (the quality of the teacher-child interaction etc.). Empirical researchers usually access measures of structural quality (turnover, staff-child ratio, share of educated and trained staff, regulation, safety, playing facilities, health and hygiene etc.), see Blau and Currie (2006). Here, we do not observe levels of structural parameters, but we argue that in terms of the share of educated and trained staff and a number of other parameters above, center based day care dominates family day care. Family day care, on the other hand, offers more flexible hours and 
the continuity of a single carer. Nonetheless, it is expected that there is excess demand for center based day care (more on this point in the next section).

We consider child care enrolment at age 2; since we evaluate consequences of type of nonparental care, our goal is to consider the earliest possible age at which a considerable share of children are enrolled in some type of care. In the calendar year in which children turn 1, only 23 \% of children are enrolled. In contrast, 56\% of the 1994/1995 (ethnic Danish) birth cohort are registered as enrolled in some form of day care in March in the calendar year in which they turn 2 The remaining share of children are taken care of at home. Table 1 shows the distribution of children born in these cohorts on types of day care. At age 1, 84\% of those enrolled are in family day care. By age 2, 75\% of those enrolled are in family day care and 25\% are in center based day care. Thus, 9 percentage points of the sample moves from family day care to center based day care at age 2. In fact, $20 \%$ of those enrolled in center based day care at age 2 had been in family day care at age 1 . In contrast, $98 \%$ of those in family day care at age 2 had been there at age 1 also. By age 3, $67 \%$ are in family care, $22 \%$ in center based day care and $11 \%$ in preschool. Finally by age 5, 99\% of the sample is enrolled in preschool.

TABLE 1 - DISTRIBUTION OF CHILDREN BORN 1994-1995

ON TYPE OF CHILD CARE GIVEN ENROLMENT, BY AGE

\begin{tabular}{lcc}
\hline & $\begin{array}{c}\text { Center-based care } \\
\text { Share }\end{array}$ & $\begin{array}{c}\text { Family day care } \\
\text { Share }\end{array}$ \\
\hline Age: & & \\
1 & 0.16 & 0.84 \\
2 & 0.25 & 0.75 \\
3 & 0.33 & 0.67 \\
4 & 0.86 & 0.14 \\
5 & 0.99 & 0.01 \\
6 & 1.00 & 0.00 \\
7 & 1.00 & 0.00 \\
\hline
\end{tabular}

Note: $56 \%$ of children are in out-of-home care in the calendar year in which they turn two. 


\section{Data and Methods}

Our starting point is the population of ethnic Danish children born in 1994-1995. ${ }^{5,6}$ We use only these two cohorts because day care enrolment started being registered from the mid-nineties and on, and we are interested in measuring long-run educational outcomes. The main data stem from administrative registers maintained by Statistics Denmark. These data provide a range of background variables describing children and their parents along with educational outcomes for the children. Control variables and educational attainment exist up until 2010. Key information on child care enrolment stems from the child care register that measures enrolment in week 10 in a given calendar year, starting in $1995 .^{7}$ Our main treatment variable therefore measures type of enrolment in the beginning of the calendar year in which the child turns 2. Information about municipal child care policies used in our instrumental variable analysis has been gathered and kindly provided to us by Bureau 2000.

\footnotetext{
${ }^{5}$ We concentrate on ethnic Danish children because our identifying strategy is based on geographical variation in access to center based care and non-ethnic Danish children often cluster in certain parts of the country. Furthermore, immigrant status is one of the few characteristics that allow children to jump the waiting lists; see Appendix A.

${ }^{6}$ Unfortunately, too few municipalities (3 adopt the policy, 3 abolish the policy) change their policy between 1996 and 1997 for us to use a difference-in-difference type strategy.

${ }^{7}$ Not all municipalities reported to the child care register in the mid-1990s. The following 20 out of 279 municipalities are excluded from our analysis: Gentofte, Græsted-Gilleleje, Køge, Ramsø, Odense, Blåvandshuk, Esbjerg, Gedved, Tørring-Uldum, Herning, Holstebro, Mariager, Spøttrup, Thisted, Viborg, Brovst, Hals, Læsø, Løgstør, and Aalborg.
} 
Table 2 shows descriptive statistics for our sample. Children minded in centers are indistinguishable from those minded by family carers in terms of their gender and APGAR scores and gestation length and show a statistically significant but only a very small difference in birth weight. The parents of children who were enrolled in centers appear to have about half a year more education, slightly lower duration of unemployment but also somewhat lower employment rates (both mothers and fathers). All parental information is measured in the year prior to the birth of the child. Parents of center minded children potentially include a sizable share of individuals out of the labour market, for instance, college students. Mothers of children in center based day care earn significantly higher incomes (3\%), while fathers only earn marginally more.

We consider three outcomes: a) standardized average of grades (end-of-year and final exam) in Danish after $9^{\text {th }}$ grade, b) standardized average of grades (end-of-year and final exam) in Math after $9^{\text {th }}$ grade, and c) an indicator for enrolling into high school before age 17 . The first two outcomes are available for both cohorts, while the latter is only available for the 1994 cohort. Table 2 shows that test scores differ between the two groups of children, with center minded children scoring between 0.1 and 0.2 standard deviations higher in terms of grade point averages. Children enrolled in center based day care are also 8 percentage points more likely to be enrolled in high school at age 16.

We consider the following model of child outcomes:

$$
E\left[O_{i} \mid X_{i}, C C_{i}\right]=X_{i} \beta+\alpha \cdot C C_{i}
$$

where $i$ indicates the child, $O$ is the observed outcome, $X$ is the conditioning set, and $C C$ indicates center based day care in the calendar year in which the child turns 2. $X$ includes 
information about the child measured at time of birth (gender, birth weight, gestation length, APGAR score, birth cohort) and parents (income, level of education, labour market attachment, age at childbirth) measured prior to the birth of the child. All analyses are carried out for the full sample and separately by subject (Danish and Math), child gender, and according to differing child socioeconomic background.

\section{TABLE 2 - SELECTED DESCRIPTIVE STATISTICS}

\begin{tabular}{|c|c|c|c|c|}
\hline \multirow[t]{2}{*}{ Variable } & \multicolumn{2}{|c|}{ Family day care at age 2} & \multicolumn{2}{|c|}{$\begin{array}{l}\text { Center based day care } \\
\text { at age } 2\end{array}$} \\
\hline & Mean & Std. Dev. & Mean & Std. Dev. \\
\hline \multicolumn{5}{|l|}{ Child: } \\
\hline Gender (0/1) & 0.51 & 0.50 & 0.51 & 0.50 \\
\hline 5-minute APGAR score & 9.70 & 1.43 & 9.68 & 1.46 \\
\hline Birthweight less than 1,500 grams & 0.005 & 0.072 & 0.004 & 0.065 \\
\hline Birthweight, 1,500-2,500 grams & 0.04 & 0.19 & 0.03 & 0.18 \\
\hline Gestation length (weeks) & 38.87 & 5.45 & 38.81 & 5.74 \\
\hline Danish GPA & -0.05 & 0.80 & 0.12 & 0.79 \\
\hline Math GPA & -0.03 & 0.91 & 0.07 & 0.92 \\
\hline High School enrolment, if born in 1994 & 0.61 & 0.49 & 0.69 & 0.46 \\
\hline \multicolumn{5}{|l|}{ Mother: } \\
\hline Age at childbirth & 29.01 & 4.47 & 29.60 & 4.64 \\
\hline High school or less & 0.33 & 0.47 & 0.34 & 0.47 \\
\hline Unemployed less than 26 weeks & 0.10 & 0.31 & 0.09 & 0.29 \\
\hline Employed in November & 0.69 & 0.46 & 0.68 & 0.47 \\
\hline Income & 198,845 & 73,719 & 208,005 & 89,403 \\
\hline \multicolumn{5}{|l|}{ Father: } \\
\hline Age at childbirth & 30.90 & 6.98 & 30.89 & 7.95 \\
\hline High school or less & 0.28 & 0.45 & 0.28 & 0.45 \\
\hline Unemployed less than 26 weeks & 0.05 & 0.21 & 0.05 & 0.22 \\
\hline Employed in November & 0.92 & 0.27 & 0.85 & 0.35 \\
\hline Income & 292,758 & 180,071 & 292,152 & 175,679 \\
\hline Number of observations & \multicolumn{2}{|c|}{14,602} & \multicolumn{2}{|c|}{46,305} \\
\hline
\end{tabular}

Note: Bold indicates that differences between family day care and preschool are significant at 5 \% level. 
Because of the likely non-random selection into types of care, we exploit as instrument that some municipalities provide guaranteed access to center based day care; see Datta Gupta and Simonsen (2010, 2012). The instrument takes the value one if the child lives in a municipality that provides guaranteed access to center based day care and is zero otherwise. Importantly, this variable is not itself a parental choice variable. The policy implies that children have the right to a slot in center based day care if they prefer, but not to a slot in a specific institution. ${ }^{8}$ If parents value this type of care over and above family day care, we expect the policy to increase the takeup of center based care. The thought experiment is as follows: Imagine two identical children. Both sets of parents prefer a slot in center based day care. But one family lives in municipality A that offers guaranteed access to care, while the other family lives in municipality B that does not. Hence the first child has a much higher chance of actually getting a slot in center based day care relative to the second child. Since the policy merely eases access to center based day care but is otherwise not restrictive, we are not concerned about monotonicity issues. ${ }^{9}$ Using 2 SLS we

${ }^{8}$ In practice, municipalities were asked whether children of new inhabitants were guaranteed a slot in center based day care.

${ }^{9}$ Of course, as discussed in Datta Gupta and Simonsen (2010) one needs to think carefully about monotonicity for a different reason: Because we have excluded the group of parents choosing home care from our analysis, we need an extended version of monotonicity, in which the choice of home care is not affected by the instrument. In our current setting, in $199647 \%$ of the children are taken care of at home in the calendar year in which they turn two in municipalities that do not guarantee center based care, whereas $54 \%$ are at home in municipalities that do provide a guarantee, suggesting that parents do not keep their children at home because they are unable to get a slot in center based care. 
estimate the LATE of center based care relative to family day care for the group of children whose parents choose center based care when there is unlimited access but not otherwise (the “compliers”).

Though the parents are not in control of the policy themselves, threats to identification occur if child care policies correlate with other characteristics, which may affect parents' location decision and the municipality's capability of providing services. The critical feature is whether the policy is correlated with child outcomes. Our robustness analyses below include information about other municipality level day care and school policies that may affect child outcomes: the price of family day care, average schooling costs per child in primary and lower secondary school, and average number of children per classroom. Conclusions are robust to this exercise. Access to the policy is not limited to certain parts of the country and that it covers both urban and rural areas. ${ }^{10}$

To shed further light on selection, however, we regress the instrument, i.e. the child lives in a municipality that provides guaranteed access to center based day care, on the variables from the main analysis. Results are shown in Table 3. A few coefficients are significant at the $10 \%$ level, which is expected with about 60,000 observations, but they point in different directions and are generally small in size. For example, increasing the father's age at childbirth with five years increases the probability of living in a municipality that guarantees access to center based care with 1 percentage point. Furthermore, we find extremely low mobility in the sample meaning that parental mobility caused by child care policies is not a large concern. In fact, $92 \%$ are

\footnotetext{
${ }^{10}$ The urban areas comprise Copenhagen and surrounding area, and the cities and surrounding areas of Aalborg, Aarhus, Esbjerg, Herning, Randers, Roskilde and Vejle.
} 
exposed to the same policy regime two years before the birth of the child in question as in the calendar year in which the child turns two. Section IV.B shows the corresponding robustness results.

Our robustness analysis also shows results using an alternative instrument that in a different way informs about access to care. In particular, we use the share of the municipality population aged 0-6 as an instrument for the type of care. Intuitively, a large child population will put pressure on center based day care and hence will lower the likelihood of center based day care. This variation, however, is not directly tied to a municipality level policy. As in the case of guaranteed access to center based day care, it is not under the control of the individual parents. As expected, our original instrument and the share of the population aged 0-6 are negatively correlated (-0.36). 
TABLE 3 - REGRESSION OF INSTRUMENT ON COVARIATES IN MAIN ANALYSIS

\begin{tabular}{l|c}
\hline Dependent variable: Instrument & OLS Coefficients \\
\hline Gender (Boy 0/1) & -0.004 \\
& $(0.005)$ \\
5-minute APGAR score & 0.00002 \\
& -0.005 \\
Birthweight less than & 0.011 \\
1,500 grams (0/1) & $(0.020)$ \\
Birthweight, 1,500- & 0.009 \\
2,500 grams (0/1) & $(0.007)$ \\
Gestation length (weeks) & 0.0001 \\
& $(0.0009)$ \\
Age at childbirth (mother) & 0.003 \\
& $(0.002)$ \\
Age at child birth (father) & $-0.002 *$ \\
& $(0.001)$ \\
High school or less (0/1) & 0.008 \\
(mother) & $(0.007)$ \\
High school or less (0/1) & 0.021 \\
(father) & $(.012)$ \\
Unemployed 13-26 & -0.029 \\
weeks (0/1) (mother) & $(0.017)$ \\
Unemployed 13-26 & 0.024 \\
weeks (0/1) (father) & $(0.018)$ \\
Unemployed more than & -0.043 \\
26 weeks (0/1) (mother) & $(0.027)$ \\
Unemployed more than & 0.065 \\
26 weeks (0/1) (father) & $(0.045)$ \\
Employed in November (0/1) & -0.024 \\
(mother) & $(0.018)$ \\
Employed in November (0/1) & -0.068 \\
(father) & $(0.056)$ \\
Gross income (2004 prices), & $0.0187 *$ \\
DKK 100,000 (mother) & $(0.009)$ \\
Gross income (2004 prices), & -0.002 \\
DKK 100,000 (father) & $(0.005)$ \\
\hline Number of obs. & 60,907 \\
& 0.0178 \\
\hline
\end{tabular}

Note: Dummies coding missing observations in variables are included. Standard errors clustered at regional level. * indicates significance at $10 \%$ level and ** at $5 \%$ level.

\section{Results}

\section{A. Main results}


Table 4 shows our main results. The first panel presents results for early high school enrolment; the second panel shows results for overall GPA in Danish; while the third gives the overall math GPA results. All standard errors are clustered at the regional level. ${ }^{11}$ Keep in mind that about 65 $\%$ of a cohort is enrolled in high school at age 16 and that GPA measures are standardized to mean 0 , standard deviation 1 at the cohort level.

The instrument affects enrolment in center based day care positively: living in a municipality with guaranteed access to center based day care increases the likelihood of enrolling with about 40 percentage points and the effect is highly significant. Including control variables does not affect the size of the first stage.

Both the OLS and the IV results indicate that enrolment in center based day care at age 2 significantly improves all outcomes, with somewhat larger IV estimates. In each case the estimated effects are remarkably similar either with or without controls. The IV analysis (with control variables) shows that early high school enrolment is increased with about 11 percentage points, GPA in Danish with 0.23 standard deviations, and GPA in Math with 0.10 standard deviations. We do expect that math skills will be less affected by attending center based day care

\footnotetext{
${ }^{11}$ As noted by Cameron and Miller (forthcoming): “...there is no formal test of the level at which to cluster. The consensus is to be conservative and avoid bias and use bigger and more aggregate clusters when possible, up to and including the point at which there is concern about having too few clusters." Our main analysis therefore clusters at the regional level but results are robust to clustering at the municipality level instead.
} 
since the curriculum is focused on socialization and language development ${ }^{12}$. Indeed, we see that this is the case, as the point estimates are smaller than in the Language case.

We also investigate heterogeneity in effects with regards to gender and maternal education; see again Table 4. Note first that the first stage coefficients are actually very similar across groups of children with different background characteristics. This suggests that guaranteeing access to center based care is equally likely to affect the chances of enrolment into center based care for boys and girls and across groups with varying maternal education. This could not be true if mothers with more education, for example, were always (or more often) able to get a slot in center based care. We find that boys consistently gain more than girls from center based day care; the effect on high school enrolment for girls is essentially zero. Effects for children born to mothers with high school or less education are systematically higher than effects for children of mothers with more education, although the latter group also show a positive and significant gain in language scores.

\footnotetext{
${ }^{12}$ Educationalists report a stronger focus on literacy versus numeracy skill development in the current Danish day care and preschool curriculum (see Jensen, 2013).
} 
TABLE 4 - EFFECTS OF CENTER BASED DAY CARE

ON LONG-RUN ACADEMIC OUTCOMES

\begin{tabular}{|c|c|c|c|c|c|c|}
\hline \multirow[t]{2}{*}{$\begin{array}{l}\text { High School } \\
\text { Enrolment }\end{array}$} & \multicolumn{2}{|c|}{ OLS } & \multicolumn{2}{|c|}{ IV w/o controls } & \multicolumn{2}{|c|}{ IV w. controls } \\
\hline & w/o controls & w. controls & 1st stage & 2nd stage & 1st stage & 2nd stage \\
\hline $\begin{array}{l}\text { All } \\
(\mathrm{N}=29921)\end{array}$ & 0.079** & $0.080 * *$ & $\begin{array}{l}0.414^{* *} \\
0.09)\end{array}$ & $0.081 * *$ & $0.403^{* *}$ & $0.105^{* *}$ \\
\hline Boys & $0.106^{* *}$ & $0.106^{* *}$ & $0.412^{* *}$ & $0.147 * *$ & $0.399 * *$ & $0.172^{* *}$ \\
\hline$(\mathrm{N}=15,256)$ & $(0.019)$ & $(0.013)$ & $(0.098)$ & $(0.027)$ & $(0.095)$ & $(0.028)$ \\
\hline Girls & $0.050 * *$ & $0.051 * *$ & $0.416^{* *}$ & 0.016 & $0.408 * *$ & 0.033 \\
\hline$(\mathrm{N}=14,665)$ & $(0.007)$ & $(0.005)$ & $(0.095)$ & $(0.020)$ & $(0.093)$ & $(0.024)$ \\
\hline Mom > H.S & $0.071^{* *}$ & $0.059 * *$ & $0.407^{* *}$ & $0.056 * *$ & $0.396 * *$ & $0.059 * *$ \\
\hline$(\mathrm{N}=19,963)$ & $(0.012)$ & $(0.008)$ & $(0.095)$ & $(0.019)$ & $(0.093)$ & $(0.024)$ \\
\hline Mom $<$ H.S & $0.101^{* *}$ & $0.115 * *$ & $0.426^{* *}$ & $0.155 * *$ & $0.415^{* *}$ & $0.179 * *$ \\
\hline$(\mathrm{N}=9,958)$ & $(0.015)$ & $(0.015)$ & $(0.098)$ & $(0.027)$ & $(0.094)$ & $(0.031)$ \\
\hline \multirow{2}{*}{$\begin{array}{l}\text { Danish GPA — } \\
\text { Overall }\end{array}$} & \multicolumn{2}{|c|}{ OLS } & \multicolumn{2}{|c|}{ IV w/o controls } & \multicolumn{2}{|c|}{ IV w. controls } \\
\hline & w/o controls & w. controls & 1st stage & 2nd stage & 1st stage & 2nd stage \\
\hline $\begin{array}{l}\text { All } \\
(\mathrm{N}=52.210)\end{array}$ & $0.170 * *$ & $\begin{array}{l}0.156 * * \\
(0.020)\end{array}$ & $0.428 * *$ & $\begin{array}{l}0.196 * * \\
(0.040)\end{array}$ & $\begin{array}{l}0.418^{* *} \\
(0.090)\end{array}$ & $0.228 * *$ \\
\hline Boys & $0.190 * *$ & $0.172^{* *}$ & $0.424^{* *}$ & $0.247 * *$ & $0.414^{* *}$ & $0.289 * *$ \\
\hline$(\mathrm{N}=25,626)$ & $(0.027)$ & $(0.022)$ & $(0.091)$ & $(0.039)$ & $(0.090)$ & $(0.042)$ \\
\hline Girls & $0.151^{* *}$ & $0.142 * *$ & $0.432^{* *}$ & $0.139 * *$ & $0.423^{* *}$ & $0.173^{* *}$ \\
\hline$(\mathrm{N}=26,584)$ & $(0.023)$ & $(0.019)$ & $(0.089)$ & $(0.038)$ & $(0.088)$ & $(0.048)$ \\
\hline Mom & $0.150 * *$ & $0.116^{* *}$ & $0.422^{* *}$ & $0.174 * *$ & $0.411^{* *}$ & $0.167 * *$ \\
\hline$(\mathrm{N}=$ & $(0.018)$ & $(0.0$ & $(0.092)$ & $(0.0$ & $(0.091)$ & 44) \\
\hline Mom $<$ H.S & $0.220^{* *}$ & $0.230 * *$ & $0.440^{* *}$ & $0.296 * *$ & $0.429 * *$ & $0.325^{* *}$ \\
\hline$(\mathrm{N}=16,219)$ & $(0.037)$ & $(0.034)$ & $(0.086)$ & $(0.057)$ & $(0.084)$ & $(0.060)$ \\
\hline \multirow{2}{*}{$\begin{array}{l}\text { Math GPA - } \\
\text { Overall }\end{array}$} & \multicolumn{2}{|c|}{ OLS } & \multicolumn{2}{|c|}{ IV w/o controls } & \multicolumn{2}{|c|}{ IV w. controls } \\
\hline & w/o controls & w. controls & 1st stage & 2nd stage & 1st stage & 2nd stage \\
\hline All & $0.105 * *$ & $0.100 * *$ & $0.429 * *$ & 0.037 & $0.419^{* *}$ & 0.099 \\
\hline$(\mathrm{N}=52,137)$ & $(0.034)$ & $(0.024)$ & $(0.090)$ & $(0.063)$ & $(0.089)$ & $(0.070)$ \\
\hline Boys & $0.128 * *$ & $0.117 * *$ & $0.425^{* *}$ & 0.080 & $0.415^{* *}$ & $0.141^{* *}$ \\
\hline$(\mathrm{N}=25,670)$ & $(0.034)$ & $(0.0233)$ & $(0.080)$ & $(0.067)$ & $(0.090)$ & $(0.070)$ \\
\hline Girls & $0.083 * *$ & $0.083^{* *}$ & $0.432 * *$ & -0.002 & $0.423^{* *}$ & 0.060 \\
\hline$(\mathrm{N}=26,467)$ & $(0.035)$ & $(0.028)$ & $(0.089)$ & $(0.060)$ & $(0.088)$ & $(0.072)$ \\
\hline Mom > H.S & $0.097 * *$ & $0.066^{* *}$ & $0.422 * *$ & 0.046 & $0.411^{* *}$ & 0.063 \\
\hline$(\mathrm{N}=35,951)$ & $(0.027)$ & $(0.018)$ & $(0.092)$ & $(0.057)$ & $(0.091)$ & $(0.063)$ \\
\hline Mom $<$ H.S & $0.134^{* *}$ & $0.162 * *$ & $0.441^{* *}$ & 0.094 & $0.430^{* *}$ & 0.146 \\
\hline$(\mathrm{N}=1$ & $(0.045)$ & $(0.042)$ & $(0.086)$ & $(0.081)$ & $(0.084)$ & $(0.094)$ \\
\hline
\end{tabular}

Note: Dummies coding missing observations in variables are included. Conditioning set includes

child, mother, and father variables. Standard errors clustered at regional level. * indicates significance at $10 \%$ level and ${ }^{* *}$ at $5 \%$ level. 
For completeness, we also discuss the coefficient estimates associated with the full set of controls for the outcome of high school enrolment. Results are available upon request. The point estimates on the controls are very similar across the OLS and $2^{\text {nd }}$ stage IV specifications. The estimated signs and magnitudes are in line with our expectations: boys are 15 percentage points less likely to enrol early in high school. Children with very low or low birth weight, low gestation length and low APGAR scores are less likely to be enrolled at age 16. The older the mother was at birth, the more likely her child is to enrol in high school, but no effect is found from father's age at birth. A parent having low education (high school or less) reduces the chances of the child enrolling in high school, by respectively, 12 (mother) and 7 (father) percentage points. The likelihood of high school enrolment decreases linearly with the duration of unemployment of both parents, and it increases only with maternal employment. Finally, not unexpectedly, gross income of either parent has only a small effect on high school enrolment in a setting where all education is fully subsidized; an increase in maternal (paternal) gross income of DKK 100,000 (about \$20,000) implies an increase in the probability of early high school of 4 (1) percentage points.

\section{B. Robustness exercises}

This subsection tests the robustness of our main results to alternative specifications in terms of conditioning sets, subsamples, and assumptions about standard errors.

Our first robustness check excludes municipalities with very low access to center based care. In practice, we exclude municipalities that do not enrol any children in center based care at age 2 . Results are robust to this exercise and shown in Table 5. The IV analysis (with control variables) 
shows that early high school enrolment is again increased with about 11 percentage points, GPA in Danish with 0.25 standard deviations, and GPA in Math with 0.13 standard deviations.

One concern with our original specification is that results may be driven by enrolment in the calendar year in which the child turns 1; if children in center based care, for example, experience fewer movements between child care providers than children in family day care, we will likely overestimate the gains from center based care. Table 6 therefore shows the main results where we exclude children enrolled in any day care before age 2 to see if variations in the day care history are behind the results; cf. discussion above. But this has basically no impact on the results.

TABLE 5 - EFFECTS OF CENTER BASED DAY CARE ON

LONG-RUN ACADEMIC OUTCOMES OMITTING MUNICIPALITIES

THAT DO NOT ENROL CHILDREN IN CENTER BASED CARE AT AGE 2

\begin{tabular}{l|ll|ll}
\hline \hline & \multicolumn{2}{|c|}{ IV w/o controls } & \multicolumn{2}{c}{ IV w. controls } \\
& 1st stage & 2nd stage & 1st stage & 2nd stage \\
\hline High School & $0.336^{* *}$ & 0.055 & $0.326^{* *}$ & $0.089^{* *}$ \\
Enrolment & $(0.061)$ & $(0.026)$ & $(0.110)$ & $(0.027)$ \\
All & & & & \\
(N=17,565) & & & & \\
\hline Danish GPA - & $0.364^{* *}$ & $0.153^{* *}$ & $0.356^{* *}$ & $0.199^{* *}$ \\
Overall & $(0.058)$ & $(0.051)$ & $(0.057)$ & $(0.059)$ \\
All & & & & \\
$(\mathrm{N}=30,421)$ & & & & \\
\hline Math GPA - & $0.365^{* *}$ & -0.041 & $0.356^{* *}$ & $0.057^{* *}$ \\
Overall & $(0.058)$ & $(0.080)$ & $(0.057)$ & $(0.094)$ \\
All & & & & \\
$(\mathrm{N}=30,375)$ & & & & \\
\hline
\end{tabular}

Note: Dummies coding missing observations in variables are included. Conditioning set includes child, mother, and father variables. Standard errors clustered at regional level. * indicates significance at $10 \%$ level and $* *$ at $5 \%$ level. 
Another concern is that there may be variation in children's exact birth months across the two types of care. On average, however, children in center based care are born 6.0 months into the calendar year whereas children in family day care are born 6.3 months into the calendar year. This small difference is not statistically significant. Furthermore, the first column of Table 7 shows that results are completely robust to the inclusion of birth month dummies. The second column of Table 7 shows results for children born in February-April when we observe them in the child care register. This selected group of children are thus all almost exactly two years old when observed to be in either family day care or center based care. Test score results are robust to this latter test but the effect on early high school enrolment is reduced in size and is not significantly different from zero.

TABLE 6 - EFFECTS OF CENTER BASED DAY CARE ON

LONG-RUN ACADEMIC OUTCOMES OMITTING CHILDREN

IN DAY CARE BEFORE AGE 2

\begin{tabular}{l|ll|ll}
\hline \hline & \multicolumn{2}{|c|}{ IV w/o controls } & \multicolumn{2}{c}{ IV w. controls } \\
& 1st stage & 2nd stage & 1st stage & 2nd stage \\
\hline High School & $0.445^{* *}$ & $0.111^{* *}$ & $0.435^{* *}$ & $0.130^{* *}$ \\
Enrolment & $(0.008)$ & $(0.021)$ & $(0.008)$ & $(0.022)$ \\
All & & & & \\
(N=22,297) & & & & \\
\hline Danish GPA - & $0.455^{* *}$ & $0.240^{* *}$ & $0.444^{* *}$ & $0.261^{* *}$ \\
Overall & $(0.006)$ & $(0.037)$ & $(0.006)$ & $(0.038)$ \\
All & & & & \\
$(\mathrm{N}=38,330)$ & & & & \\
\hline Math GPA - & $0.456^{* *}$ & 0.086 & $0.445^{* *}$ & $0.136^{* *}$ \\
Overall & $(0.006)$ & $(0.062)$ & $(0.006)$ & $(0.064)$ \\
All & & & & \\
(N=38,271) & & & & \\
\hline
\end{tabular}

Note: Dummies coding missing observations in variables are included. Conditioning set includes child, mother, and father variables. Standard errors clustered at regional level. * indicates significance at $10 \%$ level and $* *$ at $5 \%$ level. 
A third issue is birth order: it is possible that results vary with birth order simple because lowerparity children are different or because parents' child investment choices vary with birth-order (Black, Devereux and Salvanes, 2005). But having older siblings enrolled in care is also one of the few ways to circumvent waiting lists. To investigate the importance of birth order, the last column of Table 7 shows results for the sample of first-born children. Here, conclusions are unchanged.

Apart from the child characteristics investigated in this section, one may worry about systematic differences between municipalities. The first column in Web Appendix Table W1 therefore includes municipality level information about the price of family day care, average schooling costs per child in primary and lower secondary school, and average number of children per classroom. These latter variables are included to proxy quality differences in day care and schools across municipalities. This exercise actually increases the importance of center based care and the effect on math outcomes is now significant. Another municipality related concern is that large municipalities may somehow be driving the results. Column two of Table W1 therefore adds controls for the two largest municipalities (Copenhagen and Aarhus). Except for the effect on early high school enrolment that is significantly reduced in size, conclusions are unaffected by this.

Appendix Table W2 investigates more formally the consequences of movement. Here we instead base the instrument on the municipality parents lived in four years back in time (two years before the birth of the child). Results are robust to this exercise, which is not surprising given that the vast majority of parents are exposed to the same type of policy regime even four years into the past. 


\section{TABLE 7 - ROBUSTNESS ANALYSES, TIMING OF BIRTH AND BIRTH ORDER}

\begin{tabular}{|c|c|c|c|c|c|c|}
\hline & \multicolumn{2}{|c|}{$\begin{array}{l}\text { Add birthmonth } \\
\text { IV w. controls }\end{array}$} & \multicolumn{2}{|c|}{$\begin{array}{l}\text { Restrict to children } \\
\text { born Feb-April } \\
\text { IVw. controls }\end{array}$} & \multicolumn{2}{|c|}{$\begin{array}{c}\text { Restrict to } \\
\text { first-borns } \\
\text { IV w. controls }\end{array}$} \\
\hline & 1st stage & 2nd stage & 1st stage & 2nd stage & 1st stage & 2nd stage \\
\hline High School & $0.404^{* *}$ & $0.105^{* *}$ & $0.420 * *$ & 0.033 & $0.417^{* *}$ & $0.110 * *$ \\
\hline Enrollment & $(0.094)$ & $(0.023)$ & $(0.101)$ & $(0.031)$ & $(0.010)$ & $(0.021)$ \\
\hline All & \multicolumn{2}{|c|}{$(\mathrm{N}=29,921)$} & \multicolumn{2}{|c|}{$(\mathrm{N}=7,934)$} & \multicolumn{2}{|c|}{$(\mathrm{N}=14,305)$} \\
\hline Danish GPA - & $0.418^{* *}$ & $0.228^{* *}$ & $0.433^{* *}$ & $0.256^{* *}$ & $0.438 * *$ & $0.237 * *$ \\
\hline Overall & $(0.006)$ & (0.073) & (0.095) & (0.051) & $(0.007)$ & $(0.051)$ \\
\hline All & \multicolumn{2}{|c|}{$(\mathrm{N}=52,210)$} & \multicolumn{2}{|c|}{$(\mathrm{N}=14,867)$} & \multicolumn{2}{|c|}{$(\mathrm{N}=24,864)$} \\
\hline Math GPA - & $0.419 * *$ & $0.099 * *$ & $0.434 * *$ & 0.074 & $0.439 * *$ & $0.119 *$ \\
\hline Overall & $(0.005)$ & $(0.073)$ & $(0.095)$ & $(0.075)$ & $(0.007)$ & $(0.074)$ \\
\hline All & \multicolumn{2}{|c|}{$(\mathrm{N}=52,137)$} & \multicolumn{2}{|c|}{$(\mathrm{N}=14,853)$} & \multicolumn{2}{|c|}{$(\mathrm{N}=24,829)$} \\
\hline
\end{tabular}

Note: Dummies coding missing observations in variables are included. Conditioning set includes child, mother, and father variables. Standard errors clustered at regional level. * indicates significance at $10 \%$ level and $* *$ at $5 \%$ level.

Lastly, Appendix Table W3 shows results where we cluster at the municipality level and add regional dummies. Clustering at the municipality instead of the regional level has very little impact on the standard errors. Adding regional dummies weakens the first stage but the second stage results are robust and actually considerably larger in size.

Based on the range of robustness analyses in this section, we conclude that center based care significantly increases $9^{\text {th }}$ grade GPA in Danish. The effects on math are smaller in size and only sometimes significantly positive. Because the effects on high school enrolment are sensitive to variation in specifications, we are cautious about making strong conclusions about this particular outcome.

\section{Mechanisms}


Of course, it is key to think about potential mechanisms behind the positive test score results found above. An important candidate is school starting age, which has been found to significantly increase test scores, primarily due to an age-at-test effect (Black, Devereux and Salvanes (2011). If children enrolled in center based care are consistently older than children enrolled in family day care, then this may explain at least part of the estimated effects. On the outset, however, there is not much evidence of this type of behavior: $12.2 \%$ of children enrolled in center based care start school ( $1^{\text {st }}$ grade) in the calendar year in which they turn 7 (or later) compared to $14.5 \%$ of children in family day care. ${ }^{13}$ That is, children enrolled in center based care are actually slightly less likely to enrol late. Table 8 shows the results from the formal IV analysis. The effect on late school start is negative and small but significant. Thus, if anything, children enrolled in center based are younger when taking the test than children enrolled in family day care.

TABLE 8 - EFFECTS OF CENTER BASED DAY CARE ON LATE SCHOOL START

\begin{tabular}{l|rc|cc}
\hline & \multicolumn{2}{|c|}{ IV w/o controls } & \multicolumn{2}{c}{ IV w. controls } \\
& 1st stage & 2nd stage & 1st stage & 2nd stage \\
\hline School Starting & $0.413^{* *}$ & $-0.020^{* *}$ & $0.403^{* * *}$ & $-0.027^{* *}$ \\
Age $>6$ & $(0.006)$ & $(0.005)$ & $(0.006)$ & $(0.009)$ \\
All (N=47,945) & & & & \\
\hline
\end{tabular}

Note: Children enrolled in public schools. Dummies coding missing observations in variables are included. Conditioning set includes child, mother, and father variables. Standard errors clustered at regional level. * indicates significance at $10 \%$ level and ** at $5 \%$ level.

${ }^{13}$ Our data allows us to detect grade enrolment from 2007 and onwards. From the age and grade information in 2007, we are able to backtrack the school starting age. This has previously been shown to be a good approximation; see Landersø et al (2013). 
We also investigate whether results are primarily driven by the teacher rated end-of-year part of the GPA or the final exam component (earlier results were reported for the average of the two). Written final exams are the same for all children throughout the country and tests are graded both by local teachers and by external censors who do not know the child. The censor's evaluation is decisive if the teacher and censor do not agree on the final grade. In Danish language, the exam consists of both a written part and an oral part. Again, external censors are present and the grading principle is the same as in the written part of the exam. Results (not shown but available on request) indicate that the effect on teacher rated end-of-year grade (0.26 in Danish language, 0.13 in Math) is slightly higher than the effect on exam grades (0.19 in Danish language, 0.06 in Math) but the differences are not statistically significant.

\section{Alternative instrument}

Our final analysis uses instead the share of the population aged 0-6 in the municipality as an instrument for access to center based day care. Results are shown in Table 9. As expected, we see that a large child population decreases the probability of center based day care. Interestingly, the main effects are completely robust: we still see that center based day care at age 2 improved all outcomes and the size of the estimated effects is very close to those from the primary IV analysis, in fact, not statistically different from each other. 
TABLE 9 - EFFECTS OF CENTER BASED DAY CARE ON LONG-RUN ACADEMIC OUTCOMES, WHILE USING SHARE OF 0-6 YEAR OLDS IN MUNICIPALITY AS ALTERNATIVE INSTRUMENT

\begin{tabular}{l|ll|ll}
\hline \hline & \multicolumn{2}{|c|}{ IV w/o controls } & \multicolumn{2}{c}{ IV w. controls } \\
& 1st stage & 2nd stage & 1st stage & 2nd stage \\
\hline High School & $-0.119^{*}$ & 0.104 & $-0.118^{* *}$ & $0.172^{* *}$ \\
Enrolment & $(0.054)$ & $(0.074)$ & $(0.051)$ & $(0.049)$ \\
All (N=29,921) & & & & \\
\hline Danish GPA - & $-0.124^{* *}$ & $0.293^{* *}$ & $-0.120^{* *}$ & $0.381^{* *}$ \\
Overall & $(0.057)$ & $(0.098)$ & $(0.055)$ & $(0.065)$ \\
All (N=52,210) & & & & \\
\hline Math GPA - & $-0.124^{* *}$ & -0.033 & $-0.120^{* *}$ & 0.104 \\
Overall & $(0.057)$ & $(0.247)$ & $(0.055)$ & $(0.190)$ \\
All (N=52,137) & & & & \\
\hline
\end{tabular}

Note: Dummies coding missing observations in variables are included. Conditioning set includes child, mother, and father variables. Standard errors clustered at regional level. * indicates significance at $10 \%$ level and $* *$ at $5 \%$ level.

\section{Discussion and Conclusion}

This paper investigates the effects of type of non-parental care at age 2 while using Danish register-based data with key information about actual enrolment and a range of relevant background characteristics for children and parents. The analysis exploits variation in access to different types of care across municipalities.

We find that being enrolled in center based day care at age 2 significantly increases $9^{\text {th }}$ grade GPA in Danish language with around 0.2 standard deviations. Effects on math are smaller (0.1 standard deviations) and not significant in most specifications. Because most children initially enrolled in family day care eventually enrol in center based care, the appropriate interpretation of our results is as the consequence of an addition $1 \frac{1 / 2}{2}$ years of early center based care. To put the 
size of the estimated effects into perspective, the results on Danish language correspond to enrolling about seven extra students into a Swedish classroom for children aged 10-13 (Fredriksson, Öckert and Oosterbeek, 2013) or to about 200 additional school days (Carlsson, Dahl, Öckert and Rooth, 2013). We also find some evidence that the probability of being enrolled in high school at age 16 is increased as a consequence of center based day care.

Compared to the existing literature, our results are most in line with the long-term Norwegian results by Havnes and Mogstand and the more recent Spanish and German evidence by Felfe et al. (2012) and Felfe and Lalive (2013). We also confirm that center based care outperforms more informal care as suggested by Bernal and Keane (2011) for children of single mothers in the US.

Our results add a new piece of evidence to the puzzle of academic fade-out. We find long-lasting effects on achievement of attending center based care relative to more informal care, whereas a number of US studies reported in the meta-analysis by Duncan and Magnuson (2013) find that achievement effects fade out a year or two after program termination. It should be pointed out, though, that many of the 84 studies in the meta-analysis reported effects on low-income children only, and fade-out has been found to be greatest for disadvantaged children (Currie and Thomas, 2000). Fade-out is also a function of school characteristics - and is greatest when the schools that children enter following day care either have large class sizes or lower level of academic instruction in reading (Magnuson et al., 2007). Finally, fade-out is influenced by the quality and intensity of the child care experienced (Shokoff and Phillips, 2000). Since kids attending either day care or informal care in our set-up do not differ by socioeconomic background and attend the same type of (mainly, public) schools later on and furthermore, have experienced the same intensity of care use, the significant long-run effects on achievement of formal care found in our study point to a quality difference between center based care and more informal care. 
What it is then, that makes center based care so much better than the family day care alternative? Staff-to-child ratios are not very different across the two types of care but because centers are larger, the number of staff members is much higher implying that staff members can potentially learn from each other and that children have more adults to interact with. Importantly, the educational background of center based staff is, on average, much higher and much more likely to be focused on pedagogics. In fact, family day carers have characteristics that resemble those of mothers with low level education. Recent work shows that there is a high correlation between socio-economic status of the parents and the number of words spoken and conversation style (Hart and Risley, 2004), use of child-directed speech (Rowe, 2008) and use of gestures (Rowe and Goldin-Meadows, 2008), which again is predictive of later vocabulary growth and language development. Centers with more educated staff may to a greater extent mimic a high educated home environment where there is a greater verbal interaction with the child. To the extent that this represents causal effects, it may help explain our findings. In this light, it is interesting that the estimated effect of center based care on GPA in Danish language (0.2 standard deviations) corresponds to about two-thirds of the GPA gap between children born to mothers with and without at least a high school degree (0.3 standard deviations).

\section{REFERENCES}

Almond, D., Currie, J., 2011. Human capital development before age five. In: Card, D. and Ashenfelter, O. (Eds.), Handbook of Labor Economics, Elsevier, 1315-1486.

Baker, M., Gruber, J., Milligan, K., 2008. Universal child care, maternal labor supply and family well-being. Journal of Political Economy 116, 709-745. 
Bettinger, E., Hægeland, T., Rege, M., forthcoming. Home with Mom: The Effects of Stay-atHome Parents on Children's Long-Run Educational Outcomes. Journal of Labor Economics.

Bernal, R., Keane, M., 2011. Child care choices and children's cognitive achievement: the case of single mothers. Journal of Labor Economics 29, 459-512.

Black, S., Devereux, P., Løken, K. V., Salvanes, K., forthcoming. Care or Cash? The Effect of Child care Subsidies on Student Performance. Review of Economics and Statistics.

Black, S., Devereux, P., Salvanes, K., 2011. Too young to leave the nest? The effects of school starting age. Review of Economics and Statistics 93, 455-467.

Black, S., Devereux, P., Salvanes, K., 2005. The more the merrier? The effect of family size and birth order on children's education. The Quarterly Journal of Economics 120, 669-700.

Blau, D., Currie, J., 2006. Who is minding the kids. In: Welch, F., Hanushek, E. (Eds.), The Handbook of Education Economics. New York, North Holland.

Cameron, C. and D. L. Miller, forthcoming. A practitioner's guide to cluster-robust inference. Journal of Human Resources.

Carlsson, M., Dahl, G. B., Öckert, B., Rooth, D.-O., 2012. The effect of schooling on cognitive skills. NBER working paper \# 18484.

Cascio, E.U., Schanzenbach, D.W. 2013. The Impacts of Expanding Access to High-Quality Preschool Education. NBER working Paper \# 19735.

Currie, J., Thomas, D. 2000. School Quality and the Longer-Term Effects of Head Start. Journal of Human Resources, University of Wisconsin Press, vol. 35(4), pages 755-774. 
Datta Gupta, N., Smith, N., Verner, M., 2008. 'The impact of Nordic countries’ family friendly policies on employment, wages and children. Review of Economics of the Household 6, 65-89.

Datta Gupta, N., Simonsen, M., 2010. Non-cognitive child outcomes and universal high quality child care. Journal of Public Economics 94, 30-43.

Datta Gupta, N., Simonsen, M., 2012. The effects of type of non-parental child care on pre-teen skills and risky behaviour. Economics Letters 116, 622-625.

Deming, D. 2009. Early Childhood Intervention and Life-Cycle Skill Development: Evidence from Head Start. American Economic Journal: Applied Economics, 1(3): 111-34.

Duncan, G. J., Magnuson, K., 2013. Investing in Preschool Programs. Journal of Economic Perspectives, 27, 109-32.

Duncan, G. J., Sojourner, A. J., 2013. Can intensive early childhood intervention programs eliminate income-based cognitive and achievement gaps? Journal of Human Resources 48, 945968.

Dustmann, C., Raute, A., Schönberg, U., 2013. Does universal child care matter? Evidence from a large expansion in pre-school education. Mimeo, University College London.

Felfe, C., Lalive R., 2013. Does early child care help or hinder children’s development. Mimeo, University of St. Gallen.

Felfe, C., Nollenberger, N., Rodriguez-Planaz, N., forthcoming. Can’t buy mommy’s love? Universal child care and children long-term cognitive development. Journal of Population Economics. 
Goodman, R. 1997. The Strengths and Difficulties Questionnaire: A Research Note. Journal of Child Psychology and Psychiatry 38, 581-586.

Hart, B., Risley, T.R. 2004. The Early Catastrophe. Education Review, 77(1), 100-118.

Havnes, T., Mogstad, M., 2011. No child left behind: subsidized child care and children's longrun outcomes. American Economic Journal: Economic Policy 3(2), 97-129.

Heckman, J.J., 2008. Schools, skills, and synapses. Economic Inquiry 46, 289-324.

Herbst, C., Tekin, E., 2012. Child care Subsidies, Maternal Well-Being, and Child-Parent Interactions: Evidence from Three Nationally Representative Datasets," WP 1368, Princeton University.

Jensen, V.B. 2013. Børn er fødte matematikere (Children are born mathematicians). Børn \& Unge, 2013, \#6.

Landersø, R., Nielsen, H. S., Simonsen, M., 2013. School Starting Age and Crime. Mimeo, Aarhus University.

Magnuson, K. A., Ruhm, C. and Waldfogel, J. 2007. The Persistence of Preschool

Effects: Do Subsequent Classroom Experiences Matter. Early Childhood Research Quarterly, Vol. 22, No. 1, 2007, 18-38.

Rowe, M. L., 2008. Child-directed speech: relation to socioeconomic status, knowledge of child development and child vocabulary skill. Journal of Child Language 35, 185-205.

Rowe, M. L., Goldin-Meadow, S., 2008. Differences in early gesture explain SES disparities in child vocabulary size at school entry. Science 323, 951-953. 
Schönberg, U., Ludsteck, J., forthcoming. Expansions in Maternity Leave Coverage and Mothers' Labor Market Outcomes after Childbirth. Journal of Labor Economics.

Shonkoff, J., Phillips, D. (Eds.). 2000. From neurons to neighborhoods: The science of early childhood development. Washington, DC: National Academy Press.

Simonsen, M., 2010. Price of high quality day care and female employment. Scandinavian Journal of Economics 112, 570-594.

\section{APPENDIX A}

\section{Allocation of child care slots}

All children are eligible for municipality child care, including children born to unemployed parents. This means that children's right to child care enrolment is not affected by their parents' transitions in and out of the labour market. Presumably, if child care does contribute to the development of social and academic skills, we may expect such disruptions to be detrimental to learning.

Parents apply for child care (in our case either center based day care or family day care) by sending an application to the municipality. Note that the application process is the same in each case, so it is not the case that children of parents who are disorganized and file late end up in family day care. Parents enter the date from which care is needed. Upon application, children enter the waiting list. The municipality can decide whether birth date or date of application determines seniority and slots are assigned accordingly. 'Degree of need' is specifically not taken into consideration. Only if a child is disabled, is an immigrant, or if the child has older siblings enrolled in municipality provided care can he jump the waiting list. Partly for these 
reasons we include indicators for early child health, exclude immigrants, and test whether results are robust in the sample of first-borns.

Parents may indicate whether they prefer center based day care or family day care. However, children with the highest seniority are assigned the first open slot. If possible, municipalities will accommodate parents' preferences but they do not have the right to a specific slot. Parents may decline the offer they are given. If birth date is used to determine seniority, the only consequence of doing so is delaying the time until the child can enter child care, i.e. once the parents reapply, children will get the same position on the waiting list. It is clearly uncertain when the next slot is available and whether it will be of the preferred type. If seniority is determined based on time on the waiting list, the municipality may decide to blacklist parents for a limited period. Once the child is enrolled in care, he or she will no longer appear on the waiting list for alternative slots. This means that once a child is enrolled in, for example, family day care, he or she does not have the right to move to center based day care. 


\section{WEBAPPENDIX - NOT FOR PUBLICATION}

\section{TABLE W1 - ROBUSTNESS ANALYSES, MUNICIPALITY LEVEL INFORMATION}

\begin{tabular}{|c|c|c|c|c|}
\hline & \multicolumn{2}{|c|}{$\begin{array}{l}\text { Add municipality } \\
\text { variables } \\
\text { IV w. controls }\end{array}$} & \multicolumn{2}{|c|}{$\begin{array}{c}\text { And add controls for } \\
\text { Copenhagen and Aarhus } \\
\text { IV w. controls }\end{array}$} \\
\hline & 1st stage & 2nd stage & 1st stage & 2nd stage \\
\hline High School & $0.202^{* *}$ & $0.081 * *$ & $0.146 * *$ & 0.038 \\
\hline Enrollment & $(0.062)$ & $(0.033)$ & $(0.056)$ & $(0.047)$ \\
\hline \multicolumn{5}{|l|}{ All $(\mathrm{N}=29,921)$} \\
\hline Danish GPA — & $0.209 * *$ & $0.311^{* *}$ & $0.131 * *$ & $0.316^{* *}$ \\
\hline Overall & $(0.051)$ & $(0.038)$ & $(0.047)$ & $(0.062)$ \\
\hline \multicolumn{5}{|l|}{ All $(\mathrm{N}=52,210)$} \\
\hline Math GPA - & $0.210 * *$ & $0.234 * *$ & $0.132 * *$ & $0.247 * *$ \\
\hline Overall & $(0.052)$ & $(0.055)$ & $(0.047)$ & $(0.086)$ \\
\hline All $(\mathrm{N}=52,137)$ & & & & \\
\hline
\end{tabular}

Note: Dummies for missing observations included. Conditioning set includes child, mother, and father variables. Municipality variables are price of care, average schooling costs per child in primary and lower secondary school, and average number of children per classroom. Standard errors clustered at regional level. * indicates significance at $10 \%$ level and ** at $5 \%$ level. 
TABLE W2 - ROBUSTNESS ANALYSIS, STRATEGIC MOVEMENT

\begin{tabular}{l|cc}
\hline \hline & \multicolumn{2}{|c}{$\begin{array}{c}\text { Instrument based } \\
\text { on pre-birth municipality } \\
\text { IV w. controls }\end{array}$} \\
& $\begin{array}{r}\text { 1st stage } \\
\text { 2nd stage }\end{array}$ \\
\hline High School & $\begin{array}{c}0.306^{* *} \\
\text { Enrollment }\end{array}$ & $0.178^{* *}$ \\
All (N=29,921) & $0.015)$ & $(0.045)$ \\
\hline Danish GPA - & $0.330^{* *}$ & $0.388^{* *}$ \\
Overall & $(0.011)$ & $(0.110)$ \\
All (N=52,210) & & \\
\hline Math GPA - & $0.330^{* *}$ & $0.224^{* *}$ \\
Overall & $(0.011)$ & $(0.099)$ \\
All (N=52,137) & & \\
\hline
\end{tabular}

Note: Instrument based on municipality two years prior to the birth of the child in question. Dummies for missing observations included. Conditioning set includes child, mother, and father variables. Standard errors clustered at regional level. * indicates significance at $10 \%$ level and ** at $5 \%$ level.

TABLE W3 - ROBUSTNESS ANALYSES, VARYING REGIONAL DUMMIES AND CLUSTERING OPTIONS

\begin{tabular}{|c|c|c|c|c|}
\hline & \multicolumn{2}{|c|}{$\begin{array}{l}\text { No regional dummies, } \\
\text { clustering at municipality level } \\
\text { IV w. controls }\end{array}$} & \multicolumn{2}{|c|}{$\begin{array}{c}\text { Regional dummies, } \\
\text { clustering at regional leve } \\
\text { IV w. controls }\end{array}$} \\
\hline & 1st stage & 2nd stage & 1st stage & 2nd stage \\
\hline $\begin{array}{l}\text { High School } \\
\text { Enrollment } \\
\text { All }(\mathrm{N}=29,921)\end{array}$ & $\begin{array}{c}0.403^{* *} \\
(0.116)\end{array}$ & $\begin{array}{c}0.105^{* *} \\
(0.039)\end{array}$ & $\begin{array}{r}0.137 * * \\
(0.065)\end{array}$ & $\begin{array}{c}0.180^{* *} \\
(0.071)\end{array}$ \\
\hline $\begin{array}{l}\text { Danish GPA - } \\
\text { Overall } \\
\text { All }(\mathrm{N}=52,210)\end{array}$ & $\begin{array}{c}0.418^{* *} \\
(0.117)\end{array}$ & $\begin{array}{c}0.228 * * \\
(0.073)\end{array}$ & $\begin{array}{r}0.132 * * \\
(0.065)\end{array}$ & $\begin{array}{c}0.328 * * \\
(0.122)\end{array}$ \\
\hline $\begin{array}{l}\text { Math GPA - } \\
\text { Overall } \\
\text { All }(\mathrm{N}=52,137)\end{array}$ & $\begin{array}{c}0.419 * * \\
(0.117)\end{array}$ & $\begin{array}{c}0.099 \\
(0.074)\end{array}$ & $\begin{array}{r}0.133 * * \\
(0.065)\end{array}$ & $\begin{array}{c}0.390 * * \\
(0.097)\end{array}$ \\
\hline
\end{tabular}

Note: Dummies coding missing observations in variables are included. Conditioning set includes child, mother, and father variables. * indicates significance at $10 \%$ level, ** at $5 \%$ level, and $* * *$ at $1 \%$ level. 